\title{
The Indirect Effects of Discredited Stereotypes in Judgments of Jewish Leaders
}

\author{
Adam J. Berinsky Massachusetts Institute of Technology \\ Tali Mendelberg Princeton University
}

\begin{abstract}
Can stereotypes of ethnic groups have an indirect impact on voters' judgments even if voters reject them? We examine the case of Jewish leaders and hypothesize that acceptable political stereotypes (Jews are liberal) are linked in voters' minds to unacceptable social stereotypes (Jews are shady); consequently, a cue to the candidate's shadiness works indirectly by increasing the perception that the candidate is liberal, even as the shady cue is rejected. Using three national surveyexperiments we randomly varied a candidate's Jewish identity, ideology, and shadiness. The cue to the rejected social stereotype indeed activates the more legitimate political stereotype. Moreover, voters give more weight to the candidate's perceived liberalism in their evaluation. Consequently, the candidate's support suffers. However, when the candidate takes a more extreme ideological position on issues, the effects disappear. The indirect influence of discredited stereotypes and the limits of those stereotypes have implications for our understanding of voting and of the legacies of discrimination.
\end{abstract}

T ncreasingly, research on voting has recognized the crucial role that stereotypes play in shaping voters' decision making. Many recent studies of citizens have placed stereotypes or other group-centered attitudes or heuristics at the center of analysis (Gilens 1999; Gilliam and Iyengar 2000; Golebiowska 2001; Huddy and Terkildsen 1993; Kahn 1994; Kinder and Sanders 1996; Nelson and Kinder 1996; Peffley and Hurwitz 1998; Sears, Sidanius, and Bobo 2000; Sigelman et al. 1995; Sniderman and Piazza 1993; Valentino, Hutchings, and White 2002). This literature has been important in providing validation for Converse's insight that the public's beliefs are structured by attitudes toward particular groups (Converse 1964). However, as valuable as this research has been, it tends to assume that group stereotypes work at a conscious level and in a direct way. Yet there is reason to believe that stereotypes can work outside of consciousness (Mendelberg 2001; Terkildsen 1993; Valentino, Hutchings, and White 2002); if so, then perhaps stereotypes may also work indirectly. The implication of this hypothesis is that stereotypes are actually far more powerful than the voting literature recognizes.

A key to understanding the indirect operation of stereotypes is the link between rejected and accepted stereotypes. Some stereotypes are well known but disreputable and widely rejected. For example, the notions that African Americans are born with inferior intelligence and Jews are greedy were once the norm but have since passed from the realm of acceptable discourse. Other stereotypes are equally well known but widely accepted. For example, it is widely assumed that Jews and African Americans are liberal. We examine the effects of these two kinds of group stereotypes on voters' judgments of political candidates. We posit that the two kinds of stereotypes are in fact linked and that this link allows illegitimate stereotypes to continue working after they are discredited. A cue to the discredited social stereotype may activate the legitimate, political stereotype, which then becomes a more salient consideration in candidate evaluation. That is, a candidate labeled as socially stereotypical may become perceived as too liberal, and that judgment in turn may

Adam J. Berinsky is associate professor of political science, Massachusetts Institute of Technology, 77 Massachusetts Avenue, E53-459, Cambridge, MA 02139 (berinsky@mit.edu). Tali Mendelberg is associate professor of politics, Princeton University, Princeton, NJ 085441012 (talim@princeton.edu).

The authors are listed in alphabetical order. We thank Stephen Ansolabehere, Larry Bartels, Dan Carpenter, James Druckman, Martin Gilens, James Glaser, and Deborah Schildkraut for their feedback, Paul Gerber, James McGhee, and Raymond Hicks for dedicated research assistance, the Princeton University Survey Research Center and the Indiana Survey Research Center for conducting the studies, and Princeton University and the National Science Foundation's TESS project for funding.

American Journal of Political Science, Vol. 49, No. 4, October 2005, Pp. 845-864 
become the basis for rejecting the candidate. In that case, the implication is that stereotypes are politically potent long after they appear to lose their power, and stigmatized groups' overt progress toward equality is less than it appears.

Here we investigate the impact of accepted political stereotypes and of rejected social stereotypes about Jews in contemporary American elections. The experience of Joseph Lieberman, the Democratic candidate for Vice President in 2000, suggests that stereotypes of Jews do not find overt expression. Lieberman's coverage was largely positive. However, stereotypes of Jews could find a more covert form of expression, often through the acceptable trait of "liberal." The heavy attention to Lieberman's Jewish identification together with brief references to his purported negative stereotypic traits, along with anti-Jewish references to candidates in lower-level campaigns, suggest that the social stereotype of Jews is well-known in the population, is still occasionally invoked by some political actors, and could prompt voters to rely on their legitimate perception of Jews as liberal. We also selected the case of Jewish politicians because it provides a hard test of the general notion that discredited stereotypes of once subordinated groups exercise an effect indirectly, by activating acceptable stereotypes. For Jews, more than for women and African Americans, discrimination and inequality is a thing of the past in nearly every area of economic and political life. If discredited stereotypes can affect even this group, then they may be all the more powerful for groups still struggling to overcome inequality.

\section{Stereotypes and Political Cognition}

The term "stereotype" refers to a cognitive structure consisting of a category label and its corresponding traits. These traits are linked together in a coherent structure that resides in long-term memory and can become activated — ready for use — in subsequent judgments (Judd and Downing 1995). People use stereotypes in general as heuristics or shortcuts- to arrive at quick, effortless inferences and judgments (Fiske and Taylor 1984; Lippman 1922). Notably for our purpose, even when largely correct, stereotype traits are overgeneralized, resistant to contrary evidence, and may be applied in error (Allport 1954; Lippman 1922; Nelson, Acker, and Manis 1996).

Stereotypes of social groups often contain "cultural baggage" - the traces of a history of group inequality and denigration (Allport 1954; Operario and Fiske 1998, 3435). Because stereotypes continue to be conveyed in the channels of popular culture, many people know the content of these stereotypes even if they do not consciously believe in them (Devine 1989). As a consequence, negative traits continue to reside in people's cognitive representation of the group even after the group achieves a significant measure of equality. In the literature on "implicit" stereotyping, psychologists have documented that though individuals consciously reject the validity of a stereotype, it may be activated even if rejected, and used in subsequent judgments, often without intent or awareness (Banaji and Greenwald 1994; Bargh 1996; Devine 1989; Fiske 1998; Macrae, Milne, and Bodenhausen 1994; Mendelberg 2001; Wittenbrink, Judd, and Park 1997). For example, "shooter bias," in which subjects in a simulation shoot a black video character more quickly than a white character, is enhanced among subjects who perceived the existence in society of a cultural stereotype of blacks as aggressive; that is, people who merely know about the existence of the stereotype are influenced by the contents of that stereotype. The bias was not further enhanced among subjects who believed in the stereotype (Correll et al. 2002). Thus, knowledge of a stereotype may affect judgment even without a belief in the validity of the stereotype (Arkes and Tetlock 2004).

People can of course control the activation of stereotypes they reject (Devine and Vasquez 1998; Fiske and Neuberg 1990; Monteith 1993), but overriding automatically activated stereotypes is an arduous task, especially where stereotypes of social groups are concerned (Nelson, Acker, and Manis 1996; Operario and Fiske 1998). Cues to discredited social stereotypes may therefore work when people do not have a compelling alternative basis for judgment. Conversely, the cues may fail when compelling nonstereotypic information is available.

From the perspective of indirect activation, a key feature of group stereotypes is that they are rich cognitive structures whose various traits are linked in interconnected "associative networks" (Anderson 1985; Lodge and Stroh 1993; McGraw and Steenbergen 1995; Taber, Lodge, and Glathar 2001). Once a particular element of a stereotype is activated the other parts of the stereotype may become available through a process of spreading activation across the stereotype's associative network (Dovidio, Evans, and Tyler 1986; Fazio et al. 1995). ${ }^{1}$ In the Fazio et al. study, for example, the results suggest that stereotypes of blacks contain images, trait words, and evaluations, all

\footnotetext{
${ }^{1}$ For example, Fazio et al. showed pictures of whites or African Americans to white subjects, followed quickly by negative or positive trait words, and asked subjects to indicate as quickly as possible whether each word is good or bad. Subjects were quicker to classify positive traits as good when primed by white photos, and negative traits as bad when primed by African American photos.
} 
of which are linked in memory, so that one element of a stereotype can activate others linked to it. Spreadingactivation should work more powerfully when the target of judgment has both the category label and an associated trait. In that case the target appears to the perceiver to be a better fit with the stereotype than a target with the label only (Fiske et al. 1987).

Thus, it is possible that once a disavowed trait has been activated (along with the category label), it may activate another, more acceptable trait linked to it (with both linked to the category label and to each other). The disavowed trait may not influence subsequent judgments, because people will inhibit the expression of that trait. But the acceptable trait may influence judgment in its stead. ${ }^{2}$ Consequently, voters may unconsciously rely on a more legitimate component of the stereotype even if they avoid relying on a less legitimate one. The result may be erroneous and inequitable decision making about political figures.

It is important to note that activated traits may not be directly detected in subsequent tasks even as they work indirectly. Evidence for this proposition comes from an experiment that primed subjects' social stereotypes by asking them to list their thoughts about stigmatized social groups (the control subjects were not primed). Subjects whose stereotypes were primed by thought listing were better able to detect stereotypical words in a later task, even though they had not mentioned any of these words while listing their thoughts about the group (Macrae, Stangor, and Milne 1994). So it is possible that when voters' knowledge of anti-Jewish stereotypes is primed, they will not show direct evidence of stereotype activation even as they exhibit indirect activation.

\section{Social and Political Stereotype Traits}

The distinction between illegitimate and legitimate stereotypes maps fairly well onto the difference between

\footnotetext{
${ }^{2}$ The process may be akin to the "motivated reasoning" documented by Lodge, Taber, and colleagues. These authors argue that a prior belief motivates voters to process congruent information more thoroughly and to dismiss incongruent information more readily. The key point is that all the while, voters convince themselves that they have acted not out of bias but on legitimate and objective reasons (Taber, Lodge, and Glathar 2001). Evidence on this point comes from an experiment in which white voters evaluating either a liberal, moderate, or conservative black candidate perceived the liberal black candidate as less competent (Sigelman et al. 1995). Our interpretation of this result is that many voters hold a stereotype linking the category label "black" with the traits "liberal" and "incompetent," and that activating one trait in this stereotype may also activate the other.
}

social and political stereotype traits (see also Huddy 1998). Social traits describe social characteristics of groups in an exaggerated or overgeneralized manner. Many of these social stereotype traits are now considered-at the conscious level-to be violations of the modern norm that groups should be treated equally in a democracy. Political traits, by contrast, are often consciously considered an accurate representation of the way groups behave in politics, and thus are seen as legitimate beliefs. Political traits may refer to the overall orientation of a group ("Jews are liberal"), or to more specific orientations, as when women are categorized as feminist (Huddy 1998).

Research in political science has often focused on the impact of political stereotypes of political groups such as the Democratic and Republican parties (Lau 1986; Lodge, McGraw, and Stroh 1989; Rahn 1993), but recent scholarship suggests that evaluation of social groups differs from evaluation of political groups: in considering members of social groups, voters link the group's political and social traits (e.g., the social trait "masculine" with the political trait "feminist" in evaluating a female leader; Huddy 1998); Golebiowska (2001) similarly finds that voters perceive feminine gay male candidates as weaker leaders and are therefore disinclined to vote for them. So while social and political traits are distinct, they are linked in people's minds through the cognitive structure of the social group's stereotype. The social and political traits may not be related logically. Nevertheless, because of exposure to popular culture, the two are likely to be associated with each other and with the group's name in the cognitive structure of the stereotype. When a social trait is activated by a political campaign-even if that trait is considered incorrect and illegitimate-a political trait may be as well, through its link in the group stereotype.

In sum, voters are likely to view political traits as more legitimate political considerations than social traits. Consequently, if an illegitimate social trait is activated it may not receive added weight in voters' considerations because it will be consciously rejected by the individual. However, voters may give added weight to the more legitimate political trait, even if it does not apply accurately, because the overall structure of the group stereotype has been activated.

\section{Social and Political Stereotypes of Jews}

As for many social groups, the stereotype of Jews can be divided into social and political components. In the United States, the social traits of Jews as greedy, power-hungry, 
and shady have old roots and are well-known, but they have been widely repudiated as illegitimate. The political trait of liberal, however, is widely believed and relatively more socially acceptable. ${ }^{3}$ If a social trait is cued during a campaign, it may not harm a Jewish candidate's support directly, but it may do so indirectly by activating the legitimate trait of Jews as too liberal. While their contents may be unrelated, the political and social traits, together with the category label "Jew," are likely to be linked together in the memory of many voters. Thus, even if the stereotypic social trait is rejected, its mere mention may increase the salience of all components of the stereotype-including political traits.

\section{Social Stereotypes of Jews}

While it is rare that social stereotypes come directly into play in electoral politics, there are indications that they still exist in regular political discourse, even if they are often met with strong denunciation. On the national level, Patrick Buchanan has made widely condemned stereotypical references to Jews on the social dimension (Chanes 1995, 15; Foltin 1997, 142; Foltin 2000, 15152; Wertheimer 1995, 52). In a reference to the stereotyped trait of clannishness and disloyalty, Senator Ernest Hollings called Senator Howard Metzenbaum (D-Ohio) "the senator from B'nai B'rith" (Merida 1994). More significantly, the Republican National Committee during the 2000 Presidential campaign distributed "talking points" to the media calling Democratic Vice Presidential candidate Joe Lieberman "Slumlord Joe" for supposedly inheriting a slum building and stocks from his "rich uncle's" estate, and for receiving "from that uncle a portfolio of stock from other members of the 'powerful"' (McIntire 2000). Talk-radio host Rush Limbaugh also charged Lieberman with hypocrisy for inheriting from his "rich uncle" ("can you spell 'chutzpah,' Joe?!” (Limbaugh 2001)). On a local level, a recent influx of observant Jews into the small Iowa town of Postville provoked a petition signed by 126 voters (in a town of 1,600 residents) to force the first Jew appointed to the town council to run in a special election. In a newspaper interview, the mayor, who opposed the appointment, explained the opposition in classic social-stereotypic terms: "The Jewish people are not guilt-free on this. And it's not totally about religion.

\footnotetext{
${ }^{3}$ The social stereotype of Jews has a centuries-old history in the United States (Dinnerstein 1994). However, expressed levels of antiSemitism have declined dramatically over the past several decades. For example, only $16 \%$ of Americans are willing to openly endorse the statement "Jews don't care what happens to anyone but their own kind" compared to 30\% in 1964 (Smith 1993).
}

The typical Jewish person is going to bargain. The typical Jewish person will delay payment. That's not the Postville way either" (Meryhew 2001). All these cases have in common the use of social traits that have long been applied to Jews. The association between Jews and these traits has not disappeared, and because it continues to be culturally available, people know about it even if they reject it at a conscious level. ${ }^{4}$ Talk radio hosts, minor local politicians, or independently run advertisements are well-positioned to introduce discredited stereotypes, as they do with other types of slander, with most voters then exposed through media coverage of the attack.

\section{Political Stereotypes of Jews}

Though social stereotypes of Jews are discredited, political stereotypes are less so in part because they appear accurate. Since the beginning of their large-scale involvement in electoral politics during the 1930s, Jewish citizens and leaders have taken consistently liberal positions on various issues. Today they continue to be unusually liberal on a variety of social, moral, and economic issues (Cohen and Liebman 1997; Glaser 1997). Nearly $50 \%$ of Jews identify as liberal, a rate two to three times higher than that of Catholics or Protestants (Sigelman 1991).

The belief that Jews are liberal is largely accurate. But if it functions as a component of voters' overall stereotype of Jews, it might not be used accurately and judiciously in all cases. Lieberman, for example, has taken moderate and even some conservative positions on a number of policies and describes himself "as pro-business, pro-trade and pro-economic growth" (Wayne and Van Natta 2000; Wyatt 2003). His overall record is much more accurately classified as moderate than liberal. If the stereotype of Jews has potency, however, people may judge a candidate like Lieberman as more liberal than he really is. More generally, the political trait "liberal," if it functions as part of a stereotype of Jews that exaggerates and oversimplifies reality, may lead to perceptions of Jewish leaders as liberal, even when their actual positions indicate that they are not.

In sum, while most voters may reject a message that plays on the stereotypic social traits of Jews, that message

\footnotetext{
${ }^{4}$ It is not unusual for Jewish candidates to be identified by a group label. For example, in the 1990 U.S. Senate race in Minnesota, the 1998 U.S. Senate race in New York, Arlen Specter's 1995 campaign for the presidential nomination, a 1996 House race in Georgia, and a 2000 Democratic congressional primary in New York, popular press accounts characterized the candidates as "Jewish." A number of these campaigns featured accusations of anti-Semitic campaigning. (Details available from authors.)
} 


\section{TABle 1 Study 1 Design: Social and Political Stereotype Cues about the Candidate}

\begin{tabular}{lll}
\hline \multirow{2}{*}{ Social Stereotype Cue } & \multicolumn{1}{c}{ Political Stereotype Cue } \\
\cline { 2 - 3 } None & \multicolumn{1}{c}{ Liberal } & \multicolumn{1}{c}{ Conservative } \\
\cline { 2 - 3 } Label Only & Profile 1 & \multicolumn{1}{c}{ Profile 4 } \\
& Not Jewish, Not Shady, Liberal & Not Jewish, Not Shady, Conservative \\
& Profile 2 & Profile 5 \\
Label and Social Trait & Jewish, Not Shady, Liberal & Jewish, Not Shady, Conservative \\
& Profile 3 & Profile 6 \\
& Jewish, Shady, Liberal & Jewish, Shady, Conservative \\
\hline
\end{tabular}

may nevertheless activate the associative network with its various pieces, prompting some voters to give greater weight to their stereotypic political trait of Jews as too liberal-even if the message makes no allusion to the political trait. Negative, discredited social traits may not be used in evaluations of the candidate because they are deemed an unacceptable basis for judgment. However, the activation of an illegitimate social trait may in turn activate the more acceptable political trait through the cognitive stereotype structure. The candidate may lose support from the latter even as he escapes a penalty from the former.

\section{Method}

We conducted three national survey experiments to test the impact of socially legitimate and illegitimate stereotypes. The first study is designed to test the proposition that stereotypes matter in the ways we hypothesize, while the two subsequent studies take up questions left unanswered by the first. (Technical details are in the appendix.) In every study, respondents to a national phone survey were randomly assigned to listen to one of several profiles of a fictitious candidate, Howard Wilson, with each profile identical to the others except for a few words that manipulate the stereotype dimension at hand (see the appendix for wording and sample characteristics).

Table 1 shows the basic design, implemented in Study 1. The first dimension we manipulate concerns the social stereotypes of Jews. In the No-Label control condition, we did not indicate that Wilson had any particular religious or ethnic affiliation and-in order to hold the presence of scandal constant across conditions-we said Wilson was facing a lawsuit "filed against him by a business client who accuses Wilson of neglecting and ignoring his business practices." In the Label-Only condition, Wilson was iden- tified as "Jewish," and was facing the same lawsuit. In the Label and Shady condition, Wilson was identified as "Jewish" and was facing a lawsuit filed "by a business competitor who accuses Wilson of engaging in shady business practices to get ahead." In this condition, we not only cue the Jewish label, but also the social stereotypic trait (we will address reactions to a "shady" non-Jew shortly). Note that our treatment does not explicitly state that Wilson is "shady." Rather we report factual information-the details of a lawsuit-that, according to the literature on implicit stereotyping, should trigger the activation of the implicit stereotype of Jews. The respondent may therefore draw upon the Jewish political stereotype outside of conscious awareness.

This three-treatment social stereotype dimension was crossed with a two-treatment manipulation concerning political stereotypes of Jews. One-half of the respondents were given a somewhat liberal issue profile of Wilson: "Wilson has voted to raise spending on assistance to the poor" and "to increase government involvement in health care." The remaining respondents were given a somewhat conservative issue profile: "Wilson has voted to reduce spending on assistance to the poor" and "to decrease government involvement in health care." 5

After hearing their assigned candidate profile, respondents were asked to evaluate Wilson in general and

${ }^{5} \mathrm{~A}$ third issue position on tax relief for middle-class families was included for all candidates as a neutral stance. Also, following the lead of Sigelman et al. (1995), we did not provide a party label for the candidate because it would be inconsistent with some of the ideological positions we need to create. This move does not decrease our external validity. Vavreck found that "only one-third of the candidates in the 1998 midterm elections used their party label directly in advertisements" $(2001,523)$. Also, because clear party cues influence the vote decision powerfully, they could easily swamp the effect of any variable of interest in this study (Conover and Feldman 1989). Note that the three variables (ideology/religion/shady business practices) are not fully crossed with each other. There is no condition that presents a non-Jewish shady candidate. We address this omission with the later studies. 
to place him on a number of specific political attitude and trait scales (drawn from national surveys). Respondents were also asked to place themselves on some of these scales. At the end we also measured whether they accept or reject stereotypes of Jews.

\section{Legitimate and Illegitimate Stereotypes}

The first order of business is to find out whether our assumption that social stereotypes are much less legitimate than political stereotypes is correct. We asked respondents (at the end of Study 3) whether "the statement that Jews are liberal politically" is "offensive or not offensive" and the same for "the statement that Jewish businessmen are so shrewd that other people do not have a fair chance at competition." While $80 \%$ found the social stereotype offensive, only $38 \%$ found the political stereotype offensive. In addition, in Study 1 we asked how well this statement described Jews: "The trouble with Jewish businessmen is that other people do not have a fair chance at competition." Only 15\% chose either "extremely well" (5\%) or "quite well" (10\%). These results square with Smith's finding that only $22 \%$ of respondents believe that "Jews are shady" $(1993,389)$. The premise of our study is thus confirmed.

We expect that the "Jewish" label will activate the political trait attached to the stereotype of Jews and that the added invocation of the social trait will increase that activation. Therefore, we expect that (1) the description of the Jewish candidate that cues the stereotype will not cause people to judge the candidate in more socially stereotypic terms (that is, no direct activation), but (2) will cause them to judge the candidate in more politically stereotypic terms (that is, indirect activation). Specifically, our hypothesis is that Wilson will be perceived as more liberal in the "label-only" profile than in the no-label condition and more liberal still in the "label and shady" condition. If, as we expect, the link between the social and political stereotypes is sufficiently strong, then we will see this stereotype activation even in the profile that counters the political stereotype with information that the candidate is, in fact, politically conservative.

\section{The Absence of Overt Illegitimate Stereotyping}

As a first step, we ask whether the Jewish label, with or without the social trait "shady," leads voters to judge the candidate in more socially stereotypical terms. ${ }^{6}$ We expect it will not. We regressed the perception of the candidate as greedy and the perception of him as dishonest (each a 5point scale recoded to the $0-1$ interval) on a dummy variable for the "label-only" condition and another dummy variable for the "label and shady" condition. Neither the Jewish label alone nor the Jewish label with the social cue of "shady" lead people to judge Wilson as either more dishonest or more greedy. ${ }^{7}$ In all cases, the coefficients are insignificant in both a statistical and a substantive sense. Thus, as expected, the social cue does not work directly to influence perceptions of the candidate.

\section{The Indirect Effect of Illegitimate Social Stereotypes on Legitimate Political Traits}

More crucially, however, we expect these group cues to have important political consequences through the more indirect judgment of the candidate's political ideology. Our second step therefore is to test the hypothesis that cuing the Jewish stereotypes-through the "label only" and the "label and shady" conditions-will activate the political stereotypic trait of "liberal." A $2 \times 3$ between subjects ANOVA demonstrates that the two treatments (social and political stereotypes) both influence perceptions of Wilson's ideology. ${ }^{8}$ Table 2 presents the estimated means and standard errors in each of the six conditions. ${ }^{9}$ The table shows that cuing the Jewish stereotype increases the candidate's perceived liberalism. Merely identifying Wilson as Jewish pushes the respondents' impression of the candidate toward the liberal end of the 7-point scale. Adding the "shady" trait pushes it leftward still. Thus,

${ }^{6}$ All analyses omit Jewish respondents, though including them makes little difference.

${ }^{7}$ The OLS coefficients, with standard errors in parenthesis, are as follows: Greedy Candidate $=.40+.02(.03)$ Label-Only +.03 (.03) Shady; $\mathrm{n}=599$, adjusted $\mathrm{R}^{2}=-.002$. Dishonest Candidate $=$ $.40+.001(.03)$ Label-Only $-.01(.03)$ Shady; $\mathrm{n}=623$, adjusted $\mathrm{R}^{2}=-.003$.

${ }^{8}$ The overall model results are highly significant $\left(\mathrm{F}_{(3,592)}=7.95\right.$, $\mathrm{p}<.001)$, as are the political treatment effects $\left(\mathrm{F}_{(1,594)}=12.49\right.$, $\mathrm{p}<.001)$ and the social treatment effects $\left(\mathrm{F}_{(2,593)}=5.34, \mathrm{p}<\right.$ $.001)$.

${ }^{9}$ The analysis uses a 7-point branching liberal-conservative scale, where 7 is the most liberal response, and 1 is the most conservative response. We get the same results if we use only the first branch of the question, and when we use ordered probit instead of OLS. By way of calibrating the results, the ideology ratings of Joe Lieberman (the most liberal figure we asked about) and Dick Cheney (the most conservative) are 4.97 and 2.52, respectively. The significance levels are for one-tailed difference of means tests. 


\section{TABLE 2 Mean Perception of Candidate Ideology (Study 1)}

\begin{tabular}{lcc}
\hline & \multicolumn{2}{c}{ Political Stereotype } \\
\cline { 2 - 3 } & $\begin{array}{c}\text { Liberal } \\
\text { Candidate } \\
\text { Mean } \\
\text { (SE Mean) }\end{array}$ & $\begin{array}{c}\text { Conservative } \\
\text { Candidate } \\
\text { Secial Stereotype } \\
\text { (SE Mean) }\end{array}$ \\
\hline $\begin{array}{l}\text { Control Condition: } \\
\text { Not Jewish, Not Shady }\end{array}$ & $4.06(0.17)$ & $3.30(0.18)$ \\
$\begin{array}{l}\text { Label-Only Condition: } \\
\text { Jewish, Not Shady }\end{array}$ & $4.30(0.17)$ & $3.87(0.23)^{* *}$ \\
$\begin{array}{l}\text { Label and Shady Condition: } \\
\text { Jewish, Shady }\end{array}$ & $4.49(0.17)^{* *}$ & $4.07(0.19)^{* * *}$ \\
\hline
\end{tabular}

Significance levels for difference from the control condition are: ${ }^{*} \mathrm{p} \leq .10 ;{ }^{* *} \mathrm{p} \leq .05 ;{ }^{* * *} \mathrm{p} \leq .01$ (one-tailed).

There are no significant differences between the "Jewish" and "shady Jewish" conditions.

Note: Perceived candidate's ideology is a 7-point scale, $1=$ extremely conservative, $7=$ extremely liberal.

voters cued with social stereotypes seem quite ready to rely on the political stereotypic trait. ${ }^{10}$

If social stereotype traits have limited power, then when we tell voters that the candidate holds conservative issue positions, the impact of the social trait should diminish. However, Table 2 suggests that candidate information that counters the political stereotype trait does not moderate the impact of the social trait. A liberal candidate is perceived as somewhat more liberal merely for being labeled a Jew and slightly more so if he is portrayed as a "shady" Jew (the effects are in the right direction but the difference from the control candidate is statistically significant only for the shady candidate). By comparison, among the conservative candidates, the Jewish and "shady" Jewish candidates are each perceived as substantially more liberal than their counterpart in the control condition (each difference is statistically significant relative to the control candidate; the difference between the

\footnotetext{
${ }^{10} \mathrm{By}$ design we avoided extreme variance in the manipulation of candidate ideology, making it rather moderate in all conditions, in order to generalize to most contests. Some might object that this ideology treatment was too weak to impress voters. Quite possibly, a stronger ideological difference would yield different results-a hypothesis we will take up in Study 3. However, for now, the results show that voters did in fact perceive the liberal and conservative candidates differently when the stereotype cues are absent: in the control condition, the liberal and conservative candidates differ by 0.76 on the 7 -point scale ( $\mathrm{SE}=0.26, \mathrm{p}<.01$, one-tailed). This suggests that the ideology manipulation worked as intended. Voters perceived a moderate difference between two moderately different ideological profiles.
}

two "Jewish" candidates is not statistically significant). That is, a counterstereotypical, conservative description fails to counter the effect of the "shady" social stereotype trait and may even smooth the way for stereotype activation. ${ }^{11}$

\section{An Alternative Hypothesis: Perhaps "Liberal" Cues "Shady," Jewish or Not}

However, perhaps what appears to be the effect of activated stereotypes on perceptions of ideology is in fact spurious. Respondents might not associate the Jewish label and its stereotypical social traits with liberal ideology; instead, they may associate liberals (of all ethnic backgrounds) with shadiness. Perhaps if we had asked our respondents about a Protestant "shady" candidate, they would have rated him as equally liberal. In that case, it is not the stereotypic link between social and political traits that causes the increase in perception of liberal ideology; it is the independent association between liberal ideology and shadiness, ethnicity aside.

To assess the validity of this alternative hypothesis, we conducted Study 2, in which we read a national sample of citizens a randomly chosen profile out of a set of four profiles. These were identical to the "shady" profiles in Study 1, but two were of a Jewish candidate while the other two featured a Protestant candidate. The results are displayed in Table 3, which shows that the shady Jewish candidates are perceived as more liberal than their identical Protestant counterparts (the overall difference between Jewish and Protestant candidates is significant at $\mathrm{p}=0.06$, one-tailed). ${ }^{12}$

We performed an additional test of this alternative hypothesis using data from Study 1. We compared people's perception of the candidate's greed and dishonesty in the liberal and the conservative control conditions. If people associate liberal positions with greed or dishonesty without consulting their stereotype of Jews, then perceptions of the candidate's greed and dishonesty should be higher in the liberal than the conservative conditions that do not refer to Jews. The results suggest otherwise. With

\footnotetext{
${ }^{11}$ The effects in Table 2 obtain among both liberal and conservative respondents. We omitted refusals and "don't know" responses, which total $19 \%$ and do not vary significantly across conditions.

${ }^{12}$ This experiment is a $2 \times 2$ between-subjects design. An ANOVA demonstrates the significance of the treatment effects. The overall model results are highly significant $\left(\mathrm{F}_{(2,441)}=27.17, \mathrm{p}<.001\right)$, as are the political treatment effects $\left(\mathrm{F}_{(1,442)}=51.62, \mathrm{p}<.001\right)$ and the religion treatment effects $\left(\mathrm{F}_{(1,442)}=3.02, \mathrm{p}<.09\right)$.
} 


\section{Table 3 Mean Perception of Candidate Ideology, for Shady Candidates (Study 2)}

\begin{tabular}{|c|c|c|}
\hline \multirow[b]{3}{*}{ Social Stereotype } & \multicolumn{2}{|c|}{ Political Stereotype } \\
\hline & $\begin{array}{c}\text { Liberal } \\
\text { Candidate }\end{array}$ & $\begin{array}{l}\text { Conservative } \\
\text { Candidate }\end{array}$ \\
\hline & Mean (SE Mean) & Mean (SE Mean) \\
\hline Protestant Label & $4.35(0.18)$ & $3.09(0.17)$ \\
\hline Jewish Label & $4.63(0.16)$ & $3.37(0.17)$ \\
\hline
\end{tabular}

Note: Perceived candidate's ideology is a 7-point scale, $1=$ extremely conservative, $7=$ extremely liberal. Overall difference between Jewish and Protestant is significant at .06 level (one-tailed).

the 7-point perceptions of ideology recoded to the 0 to 1 interval for ease of interpretation $(1=$ liberal $)$, the unstandardized OLS estimate on a dummy variable coded 1 for the liberal control condition and 0 for the conservative control condition is -.05 for "greedy," with a standard error of .04. The results for the "dishonest" item are even clearer, with the coefficient on the dummy variable at 003 $(\mathrm{SE}=.04)$. Liberal ideology without a group label does not seem to lead to perceived shadiness.

In sum, there is no evidence for the alternative hypothesis that voters associate a candidate's shadiness with liberal ideology, his ethnic membership notwithstanding. An ideal design would of course combine Studies 1 and 2 , running all eight conditions simultaneously. However, that design now seems unnecessary, since the alternative hypothesis it would test gets no support when our two studies and the additional test reported above are taken together. We can now be more confident that the social trait of shadiness is linked in voters' minds to the political trait of liberalness specifically through the group stereotype.

\section{Social Traits Working Through Political Traits: Candidate Evaluation}

As important as the movement in perception of liberal ideology is the question of whether candidates incur a political penalty from stereotypes. Once the liberal trait is activated, it may become more accessible and therefore more likely to be used in judgment. This could be a simple cognitive process in which an activated trait automatically becomes more ready for subsequent use and thus gains more weight in the decision making. Alternatively, the process could be driven by motivated reasoning. Voters may first dislike Wilson because he is a "shady Jew"perhaps out of awareness of the stereotype-and then justify their dislike by relying more heavily on his perceived ideology. In the first case, the candidate's perceived liberal ideology provides voters a stronger reason to oppose him either when he is Jewish or when he is a "shady Jew." "I In the second case, the candidate's perceived liberal ideology gives voters a stronger reason to oppose him when he is portrayed as a "shady Jew." We do not seek to adjudicate between these explanations, but instead offer them as a basis for the prediction that liberal/conservative placement of the candidate will carry more weight in the shady Jewish condition and possibly also in the Jewishonly condition.

To test this hypothesis, we regressed the 100-point feeling thermometer for the candidate on perceptions of the candidate's ideology in each condition in Study 1. We estimated separate models for the liberal and conservative candidates for ease of interpretation. The model includes two dummy variables representing the Labelonly and Shady conditions, with the non-Jewish candidate as the excluded condition. It also includes two interaction terms that multiply the 7-point perception of candidate ideology (scaled $0-1$ ) by each condition's dummy variable. Finally, we include a term for perceived ideology to capture the impact of perceived ideology in the excluded control condition. This setup allows the effect of ideological placement to vary by condition. We ran our analysis separately for self-identified liberal and conservative respondents. ${ }^{14}$ For conservative voters the candidate's perceived liberal ideology would constitute grounds for rejection, but for liberal voters, the candidate's liberal ideology would not be a liability and, in fact, could be an asset.

The OLS coefficients and standard errors are presented in Table 4, and for ease of interpretation and to conform to the style of ANOVA presentations, the corresponding estimated means are presented in Table 5. ${ }^{15}$ Recall that many voters tend to misperceive the socially stereotyped Jewish candidate in more politically stereotyped terms, that is, as more liberal. Tables 4 and 5 suggest that conservative voters go the next step and give more weight to their exaggerated perception when evaluating

\footnotetext{
${ }^{13}$ Though perhaps the cognitive links leading to "liberal" are stronger for "shady Jew" than for merely "Jewish."

${ }^{14}$ For this analysis we classified a respondent as liberal/conservative if they considered themselves as such or leaned liberal/conservative "if forced to choose."

${ }^{15}$ We tested the robustness of these results by reestimating the model with additional control variables (party identification, education, and age). The coefficients we present here did not change in any significant way with these additional variables.
} 


\section{TABLE 4 The Impact of Perceived Candidate Ideology on Candidate Evaluation (Study 1)}

\begin{tabular}{|c|c|}
\hline \multicolumn{2}{|l|}{ Conservative Voters } \\
\hline Liberal Candidate & Coefficient (SE) \\
\hline $\begin{array}{l}\text { Constant } \\
\text { Label-Only Condition (Jewish, Not Shady) } \\
\text { Shady and Label Condition (Jewish, Shady) } \\
\text { Perceived Ideology } \\
\text { Perceived Ideology } * \text { Label-Only Condition } \\
\text { Perceived Ideology } * \text { Shady and Label Condition } \\
\qquad \mathrm{N}=155 \text { Adj } \mathrm{R}^{2}=0.11\end{array}$ & $\begin{aligned} 59.69 & (4.21)^{* * *} \\
-8.70 & (6.55) \\
1.94 & (6.19) \\
-19.49 & (6.86)^{* * *} \\
16.73 & (10.67) \\
-9.21 & (10.15)\end{aligned}$ \\
\hline Conservative Candidate & Coefficient (SE) \\
\hline $\begin{array}{l}\text { Constant } \\
\text { Label-Only Condition (Jewish, Not Shady) } \\
\text { Shady and Label Condition (Jewish, Shady) } \\
\text { Perceived Ideology } \\
\text { Perceived Ideology } * \text { Label-Only Condition } \\
\text { Perceived Ideology } * \text { Shady and Label Condition } \\
\qquad \begin{array}{l}\mathrm{N}=153 \text { Adj } \mathrm{R}^{2}=0.16 \\
\text { Liberal Voters }\end{array}\end{array}$ & $\begin{aligned} & 55.65(4.99)^{* * *} \\
&-3.73(7.17) \\
& 10.80(7.68) \\
&-18.44(9.04)^{* *} \\
&-1.41(11.90) \\
&-23.19(13.01)^{*}\end{aligned}$ \\
\hline Liberal Candidate & Coefficient (SE) \\
\hline $\begin{array}{l}\text { Constant } \\
\text { Label-Only Condition (Jewish, Not Shady) } \\
\text { Shady and Label Condition (Jewish, Shady) } \\
\text { Perceived Ideology } \\
\text { Perceived Ideology } * \text { Label-Only Condition } \\
\text { Perceived Ideology } * \text { Shady and Label Condition } \\
\qquad \mathrm{N}=129 \text { Adj } \mathrm{R}^{2}=0.08\end{array}$ & $\begin{array}{r}45.16(6.15)^{* * *} \\
0.12(8.36) \\
-10.77(8.76) \\
0.67(10.40) \\
16.23(13.97) \\
23.52(13.83)^{*}\end{array}$ \\
\hline Conservative Candidate & Coefficient (SE) \\
\hline $\begin{array}{l}\text { Constant } \\
\text { Label-Only Condition (Jewish, Not Shady) } \\
\text { Shady and Label Condition (Jewish, Shady) } \\
\text { Perceived Ideology } \\
\text { Perceived Ideology } * \text { Label-Only Condition } \\
\text { Perceived Ideology } * \text { Shady and Label Condition } \\
\qquad \mathrm{N}=113 \text { Adj } \mathrm{R}^{2}=0.03\end{array}$ & $\begin{array}{l}31.78(4.07)^{* * *} \\
4.54(5.94) \\
13.40(7.01)^{*} \\
29.88(11.54)^{* *} \\
-21.31(14.09) \\
-40.51(15.39)^{* * *}\end{array}$ \\
\hline
\end{tabular}

${ }^{*} \mathrm{p} \leq .10 ;{ }^{* *} \mathrm{p} \leq .05 ;{ }^{* * *} \mathrm{p} \leq .01$ (two-tailed).

Candidate evaluation is a 100-point scale, $100=$ warmest, $0=$ coolest.

Perceived candidate ideology is a 7 -point scale, $1=$ extremely liberal, $0=$ extremely conservative.

the candidate. Table 4 shows that in comparison with the control and "label-only" conditions, the "shady" trait leads conservative voters to give more weight to their perception of the candidate's ideology in their evaluation of the candidate. This holds especially for the conservative candidate $(b=-23.19$, se $=13.01$; differences from "label-only" and from control are each significant at $\mathrm{p} \leq .0$ ); the effect for the liberal candidate is not significant though in the expected direction $(b=-9.21$, se $=10.15) .{ }^{16}$ That is, the "shady" Jew's extra penaltybeyond that suffered by the non-Jew-from being perceived as liberal rather than as conservative is 9 points

\footnotetext{
${ }^{16}$ Tests on differences between the effects of perceived ideology in control versus the shady or label conditions are t-tests since the coefficients in these conditions in themselves are the differences in effects from the control condition. We report two-tailed tests for these t-tests. Tests on the differences between conditions other than the control are F-tests.
} 


\section{TABLE 5 Estimated Mean Effects of Perceived Ideology on Candidate Evaluation (Study 1)}

\begin{tabular}{|c|c|c|c|c|c|c|}
\hline \multirow[b]{3}{*}{ Social Stereotype } & \multicolumn{6}{|c|}{ Political Stereotype } \\
\hline & \multicolumn{3}{|c|}{ Liberal Candidate } & \multicolumn{3}{|c|}{ Conservative Candidate } \\
\hline & $\begin{array}{c}\text { Perceived } \\
\text { Liberal }\end{array}$ & $\begin{array}{c}\text { Perceived } \\
\text { Conservative }\end{array}$ & $\begin{array}{c}\text { Liberal - } \\
\text { Conservative }\end{array}$ & $\begin{array}{c}\text { Perceived } \\
\text { Liberal }\end{array}$ & $\begin{array}{c}\text { Perceived } \\
\text { Conservative }\end{array}$ & $\begin{array}{c}\text { Liberal- } \\
\text { Conservative }\end{array}$ \\
\hline & \multicolumn{6}{|c|}{ Conservative Voters, Estimated Means } \\
\hline Control Condition & 40 & 60 & -20 & 37 & 56 & -19 \\
\hline Label-Only Condition & 48 & 51 & -3 & 32 & 52 & -20 \\
\hline \multirow[t]{2}{*}{ Shady and Label Condition } & 33 & 62 & -29 & 25 & 67 & -42 \\
\hline & \multicolumn{6}{|c|}{ Liberal Voters, Estimated Means } \\
\hline Control Condition & 46 & 45 & 1 & 61 & 32 & 29 \\
\hline Label-Only Condition & 62 & 45 & 17 & 45 & 36 & 9 \\
\hline Shady and Label Condition & 60 & 34 & 26 & 34 & 46 & -12 \\
\hline
\end{tabular}

if he is liberal and 23 points if he is conservative. The candidate's actual conservative positions do not appear to inhibit indirect stereotyping, since the conservative candidate is stereotyped more than the liberal candidate. Moreover, it is the category label of "Jewish" along with the cue to the social stereotype trait of "shady," and not the "Jewish" label alone, that sets indirect stereotyping in motion (the impact of perceived ideology when the candidate is Jewish is not statistically distinguishable from the impact in the liberal candidate control condition).

To make the results more clear, Table 5 presents the estimated means calculated from the regression coefficients (for the extreme values of the perceived ideology scale). ${ }^{17}$ The "shady" Jewish candidate's support among conservative voters drops by between 29 and 42 thermometer points (for the liberal and conservative candidates, respectively) when he is perceived as extremely liberal relative to extremely conservative, while the corresponding drop in points for the non-Jewish candidate is between 20 and 19 points. Put differently, a candidate perceived as extremely liberal suffers by 7 to 12 points more when he is characterized as a shady Jew than when he is a non-Jew; by contrast, the candidate's support drops not at all when he is perceived as extremely conservative. ${ }^{18}$ It is only by being perceived as liberal that the shady Jewish candidate suffers a drop in support.

Liberal voters' evaluations exhibit a less consistent pattern. They are colder with the invocation of the social

\footnotetext{
${ }^{17}$ Scores on the perceived ideology scale run from 0 to 1 for conservative voters and for liberal voters given the liberal control case. For liberal voters given the conservative control case, the perceived ideology scale runs from 0 to .83 .

${ }^{18}$ The means are for the liberal and conservative candidates, respectively.
}

stereotype, but only for the conservative candidate. Table 4 shows that when the conservative candidate is not Jewish, his perceived liberalism is a reason to support him $(b=29.88$, se $=11.54)$. But when he is a "shady" Jew, his perceived liberalism is no longer an advantage. The difference between the effects of perceived ideology in the control and "shady" conditions is 41 points and statistically significant $(\mathrm{p} \leq .01)$. Again, the Jewish label alone carries no statistically significant ill effects or benefits relative to the control condition. These results hold only for the conservative candidate; contrary to expectations, the liberal candidate suffers no ill effects from the social stereotype, and even appears to benefit from it, though the control baseline effect of ideology here is essentially zero and thus not a trustworthy comparison point for that conclusion. ${ }^{19}$

In sum, we found evidence for the indirect effect of a social stereotype cue. These effects work differently for self-identified liberals and conservatives. Conservatives not only see the "shady" Jewish candidate as more liberal than his non-Jewish counterpart, but also find that candidate's liberal ideology much more objectionable. The mere group label does not carry ill effects; the candidate suffers a more severe penalty for his misperceived issue

\footnotetext{
${ }^{19}$ In Study 1, liberal voters evaluating the non-Jewish liberal candidate do not favor the candidate when they perceive him as more liberal, which makes for an odd baseline. All the other control groups we examined, in Study 1 and Study 3, favored the candidate close to them ideologically. If the baseline effect resembled those others, it would be between 16 and 30 points, and there would be no statistical difference with the shady condition. The net effect in the shady condition for the conservative candidate appears to be negative $(-12)$, but statistically it is indistinguishable from zero. Perhaps liberals reject a candidate they perceive as an in-group member ideologically but an out-group member ethnically.
} 
positions only if he is identified as a socially stereotypic group member. Thus, the process of stereotyping is indirect: the social trait ("shady"), working with the category label "Jew," activates a stereotyped political trait ("liberal"), which in turn decreases support. Without the perceived political trait, the social cue does nothing to erode the candidate's support. ${ }^{20}$ That the penalty accrues most consistently among conservative voters makes sense given that these are the voters most likely to reject a candidate perceived as liberal. What is especially striking here is the inability of the candidate who takes actual conservative positions to escape the consequences of indirect stereotyping. Among liberal respondents, we found a somewhat different pattern of results; liberals also respond to the social stereotype cue, but do so less consistently. One might expect that if liberal voters perceive a candidate as more liberal that the candidate would benefit from that perception, but the shady Jewish candidate does not always reap this reward. In other words, liberal voters seem to apply a more subtle if strong penalty to some socially stereotyped candidates by withholding the support they would otherwise offer due to the candidate's liberal ideology. Thus, though the results among liberal voters are not always as expected, for three out of four tests the social stereotype is a liability for candidates.

\section{When Illegitimate Stereotypes Fail}

Is there a limiting condition to these stereotype effects? If so, perhaps the answer lies with the clarity of the available information about issues and ideology. So far, we have assumed that voters often find it difficult to glean from candidate communication a set of clear and differentiated positions on issues. And in fact, American politics generally offers up candidates who shy away from extreme ideological positions (Page 1978). However, sometimes candidates do make clear where they stand on polarizing issues. When they do, it stands to reason that voters will find it easier to lean more heavily on these stands, and in turn, may lean less heavily on cues to group stereotypes. That view rests on the assumption that voters often use group cues as a type of heuristic in drawing inferences about candidates. We do know, in fact, that voters often rely on information shortcuts in elections (Lau and Redlawsk

\footnotetext{
${ }^{20} \mathrm{We}$ get the same results when we recode the feeling thermometer to three categories (positive, 51-100; neutral, 50; negative, 0-49), and stronger results when we focus on voters who gave feeling thermometer ratings other than 50. Adding missing responses to the analysis by recoding "don't know" and refusal responses to " 50 " does not change the results.
}

\section{TABle 6 Mean Perception of Candidate Ideology (Study 3)}

\begin{tabular}{lcc}
\hline & \multicolumn{2}{c}{ Political Stereotype } \\
\cline { 2 - 3 } & $\begin{array}{c}\text { Liberal } \\
\text { Candidate } \\
\text { Mean } \\
\text { (SE Mean) }\end{array}$ & $\begin{array}{c}\text { Conservative } \\
\text { Candidate } \\
\text { Mean } \\
\text { (SE Mean) }\end{array}$ \\
\hline $\begin{array}{l}\text { Social Stereotype } \\
\text { Control Condition } \\
\text { Not Shady, Not Jewish }\end{array}$ & $5.12(0.16)$ & $3.58(0.20)$ \\
$\begin{array}{l}\text { Label-Only Condition } \\
\text { Jewish, Not Shady }\end{array}$ & $4.96(0.15)$ & $3.42(0.18)$ \\
$\begin{array}{l}\text { Shady and No Label } \\
\text { Condition Not Jewish, } \\
\text { Shady }\end{array}$ & $5.12(0.14)$ & $3.39(0.20)$ \\
$\begin{array}{l}\text { Shady and Label Condition } \\
\text { Jewish, Shady }\end{array}$ & $4.94(0.16)$ & $3.60(0.20)$ \\
\hline
\end{tabular}

Note: There are no statistically significant differences across the conditions within the political stereotypes. However, the differences between the liberal candidate conditions and the conservative candidate conditions are significant at the 0.01 level.

2001; McDermott 1997). Moreover, perhaps voters fall back on these heuristics especially when they do not find easily digestible information about issues and ideology. ${ }^{21}$ If heuristic use-to be exact, heuristic misuse-declines when voters are given more diagnostic information about candidates' positions, then we should see less reliance on the Jewish stereotype and more reliance on issues when the candidate is ideologically extreme in his issue stances.

In Study 3 we test this proposition. Here we again surveyed a national sample by phone, but each candidate was profiled in sharper relief as either an extreme liberal or an extreme conservative. As in Studies 1 and 2, we again provided a position for the candidate on government spending to assist the poor, but this time, the candidate sought either to "greatly raise" or "greatly reduce" this spending (as opposed to "raise" and "reduce" in Studies 1 and 2). In Study 3 we also combine the conditions from Study 1 and Study 2 for a design with eight conditions.

Table 6 presents the results of Study 3, replicating the analytic strategy of Study 1 (from Table 2 ). ${ }^{22}$ Once the

\footnotetext{
${ }^{21}$ It does appear that voters' use of heuristics changes in response to changes in the issue positions provided by candidates (Lau and Redlawsk 2001).

${ }^{22}$ This experiment is a $2 \times 2 \times 2$ between-subjects design. The overall model results are highly significant $\left(\mathrm{F}_{(3,1149)}=48.81\right.$, $\mathrm{p}<.001)$. But only the political treatment effect is significant $\left(\mathrm{F}_{(1,1151)}=48.81, \mathrm{p}<.001\right)$ not the religion treatment effects $\left(F_{(1,1151)}=0.47, n s\right)$ or the "shady" treatment $\left(F_{(1,1151)}=0.00, n s\right)$.
} 
ideological profiles are strengthened, a Jewish candidate is no more likely to be rated liberal than a non-Jew, even when he is shady. And unlike in Study 2, the shady Jewish candidate is no more likely to be rated liberal than a shady non-Jew. In addition, the effects of stereotype cues on candidate evaluation are substantially weaker in Study 3, with only one effect clearly reaching significance (see Table A1 in the appendix). ${ }^{23}$

But is the absence of stereotype effects in Study 3 really caused by the fact that respondents relied on the stronger ideological issue cues? ${ }^{24}$ To more directly investigate that hypothesis, we conducted two sets of tests.

In the first test, we compared the mean ideological placements of the candidates. We found that respondents viewed the candidates as more ideologically extreme in Study 3 than in Study 1. Across all conditions, in Study 1 the average difference between the liberal and conservative candidates is . 50 , while in Study 3 the average difference is $1.54-$ more than three times as large. Moreover, the percentage of voters choosing the most extreme endpoints of the 7-point placement scale is $18 \%$ in Study 1 but $40 \%$ in Study $3 .^{25}$

Second, we examined the respondents' knowledge of the candidate's issue positions. If the candidate's more extreme position is the cause of the results of Study 3, then voters should better recall the candidate's true issue position. While our questions concerning the candidate's issue positions were not identical across studies, nevertheless, because both questions deal with the candidate's position on government spending for services, we believe that they are sufficiently comparable to allow for an informative contrast between studies. ${ }^{26}$ Pooling the six common conditions across the two studies, the percentage of people who correctly classify the candidate's issue position is

${ }^{23}$ We do not observe any other effects of ethnic cues in Study 3, whether the cue is the Jewish label alone or with the "shady" trait. Results are available upon request.

${ }^{24}$ We investigated the possibility that the original effects we uncovered in the first two studies were not replicated because the samples were dissimilar. However, we found that the samples were indeed similar on relevant dimensions (see Appendix). Thus, sample variation cannot explain the findings.

${ }^{25}$ The mean ideological difference in the control conditions between the liberal and conservative candidates was 0.76 in Study 1 and 1.54 in Study 3.

${ }^{26}$ In Study 3 we asked "How about Howard Wilson's position on spending on the poor? Do you remember if he thinks federal spending on poor people should be increased, decreased, or kept about the same?" In Study 1 we asked "What about Howard Wilson? Do you think he would like the government to provide fewer services in order to reduce spending, provide more services even if it means an increase in spending, or continue at the present level?" There is no reason to expect a priori that one version would yield a bigger impact than the other.
$79 \%$ in Study 3 versus 55\% in Study 1. Clearly, the respondents were more accurate in their placements when the ideological cue was sharper. ${ }^{27}$

In sum, Study 3 suggests the limiting condition on the effect of discredited stereotypes. The effect exists only when ideology cues are more ambiguous and disappears when these cues are more clear and salient. Stereotypes appear to diminish when voters rely on accurate information about the candidate's stands.

\section{Conclusion}

We have attempted to gauge whether negative stereotypes of a social group work in a subtle yet potent fashion. We focused on stereotypes of Jews as a difficult test of this hypothesis. Surveys have shown consistently that negative stereotypes of Jews have declined dramatically in the United States. Yet the results here suggest that when campaigns cue stereotypic social traits-even those widely discredited-they may prompt indirectly a process of stereotyping by which Jewish candidates could lose political support.

This process, it seems, is both cognitive and affective. It is cognitive in the sense that stereotypic social and political traits are linked together within a cognitive structure that resides in memory. The discredited social traits are activated but controlled, while the more legitimate political trait is activated and not overridden. Because the social is linked to the political, stereotyping can carry an important indirect consequence for political judgments. But stereotyping is not only cognitive, it can also be evaluative. Many of the social stereotype traits of social groups with a history of disadvantage are negative. We found that only when a negative social trait is cued does the target of the stereotype suffer adverse consequences; the group label, which is evaluatively neutral, causes little harm by itself.

Whether our findings apply to Lieberman's candidacy is uncertain. First, hearing information about a candidate over the phone may not be the same as exposure to a

\footnotetext{
${ }^{27}$ Moreover, the impact of accurate issue placement on ideological placement of the candidate should be larger in Study 3-if people are relying more on correct issue placements to judge the candidate's ideology. To find out, we regressed the familiar measure of perceived candidate ideology on candidate issue placement (coded so that -1 is decrease spending, 0 is the status quo, and 1 is increase spending), on a dummy variable for the accuracy (1) or inaccuracy (0) of that issue placement, and on the interaction of these two variables. The results demonstrate that only in study 3 do people rely on the correct issue placement in judging the candidate's ideology. If the candidate does not take a clear position on the issue, then voters may rely on ethnic cues instead of correct issue placements, and bias enters their decision making.
} 
series of stories in the media. In the more informationrich context of a campaign, stereotypic labels and information may play either a greater or a lesser role, though we note that most campaigns resemble our simulation in being rather information-poor environments in which voters typically know very little about candidates. Further work could explore these contextual effects. Second, Lieberman's candidacy does not fit our "label-only" simulation, since his campaign and press coverage highlighted not only the Jewish label but also the socially stereotypic trait of religiosity. Neither does his candidacy clearly fit our social trait condition. The trait of religiosity, while social, is much more positive than the trait of shadiness. However, there was an element of the 2000 campaign that resembles the cue we studied here. As we noted earlier, for a brief time, Lieberman was (falsely) accused by the Republican National Committee as a "slumlord" and stockholder in "powerful" companies (McIntire 2000). If we extrapolate from the fact that the label-only condition did not produce stereotyping effects, then we could tentatively conclude that positive references to a candidate's ethnicity would do no harm. On the other hand, if strong links exist between stereotype traits regardless of whether they are positive, negative or neutral, then cues to positive traits (such as religiosity) could in turn activate negative traits.

What we can say with some confidence is that absent positive information about a Jewish candidate, intensive attention to a candidate's Jewish ethnicity is likely to pose a liability with an electorate composed of more than trivial numbers of conservative voters because many of these voters will infer that he is too liberal. Moreover, if a Jewish candidate were to run against a candidate in the mold of Patrick Buchanan (who has made consistent statements unfavorable to Jews), or in an environment rife with tensions between Jews and others (as in the Iowa town of Postville, or at certain moments in New York City), the candidate may find himself or herself characterized in negative stereotypical terms. It may not be the opposing candidate who does so; cues might present themselves in the course of casual exchange among ordinary political discussion partners, on talk radio, or in internet forums. Regardless of their source, if such cues are available, antiJewish stereotypes may well become activated. The consequence will likely be the erosion of the Jewish candidate's support.

The process by which Jewish candidates' support can erode is an indirect one, and thus potentially difficult to counter. Voters primed with explicit, illegitimate stereotype cues do not come to perceive the candidate in those terms. Thus, voters do not reject the candidate because he is a dishonest or greedy person. Rather, voters rely on their misperceived reading of the candidate's ideology. The cue to the negative social trait sets in motion a process by which the candidate is perceived as more liberal, and in turn judged more harshly for it.

But the temptation that this presents for candidatesto inoculate themselves by moving slightly rightward-is probably a false one. Most likely, a candidate's attempt to present a moderately conservative policy profile will fail and may even backfire. The results presented here suggest that moderately conservative candidates can no more escape the effects of stereotyping than can moderately liberal candidates. Thus the strategy that may seem most sensible is unlikely to succeed.

However, our last study showed that when candidates are on the ideological extreme, voters do jettison stereotypical inferences. So in highly conservative environments, Jewish candidates may be best off moving to the extreme right. Whether a candidate gains more votes than he loses by moving to the extreme is unclear. In any case, this limiting condition is rare in the real world, where candidates often try to occupy the moderate middle ground and to cast their issue positions in vague terms. These are the conditions we simulated in our first study, in which we found indirect stereotyping, so indirect stereotyping may exist as long as members of ethnic groups run for office in an environment hostile to sharp and clear ideological extremes. These results suggest that stereotypes may play a powerful role in structuring political evaluations in actual campaigns.

A strategy that these results can more plausibly recommend takes as its point of departure the indirect nature of the stereotype process. If voters come to understand that their response derives from stereotypes that are widely repudiated, they may be more motivated to override the activation of the stereotype. The psychological literature on stereotypes provides some hope in this regard. When people are motivated to interfere with the activation of their own stereotypes, they can often weaken the impact of their stereotypes on their judgments, if not completely eradicate it (e.g., Bodenhausen and Macrae 1998; Devine 1989; for a somewhat more pessimistic conclusion, see Nelson, Acker, and Manis 1996). ${ }^{28}$

Because we picked a hard case as our test-a group whose history of inequality and stigmatization is relatively

\footnotetext{
${ }^{28}$ The political stereotyping process may also apply outside the context of campaigns. Recent news stories about jury selection suggest that Jews may be disproportionately excluded in some locales because prosecutors believe that "no Jew would vote to send a defendant to the gas chamber." One former prosecutor justified the exclusion of Jews, which in Alameda county, California, extended to $93 \%$ of those with Jewish last names versus $50 \%$ of others, as "not a racist thing" but because "their politics are not going to be on your side" (Murphy 2005, A1).
} 
distant-the results here may plausibly generalize to a variety of groups with a more contemporary experience of inequality and stereotyping, including African Americans and Hispanics. Although the social traits vary across groups, the framework we provide should nevertheless apply. The distinction between social and political group traits, and the corresponding distinction between illegitimate and legitimate stereotypes, may play an important role regardless of the content of the social trait. The dynamics of the process may well be similar, with discredited stereotypes continuing to work through the legitimate political trait of liberal ideology, but subject to the same condition of ideological moderation. We do caution, however, that when conflict is deep, the limiting condition we found may not hold, and stereotypes may work even with salient, clear cues to ideology and issue positions.

Today, members of social groups with a history of disadvantage are protected from harm by virtue of their citizenship in a democracy. But those among them who seek to join the governing class may, under specific circumstances, continue to face obstacles rooted in social suspicion. The key to the remedy is to understand those circumstances and to investigate the ways in which they might be neutralized.

\section{Appendix A}

TABle A1 The Impact of Perceived Candidate Ideology on Candidate Evaluation (Study 3)

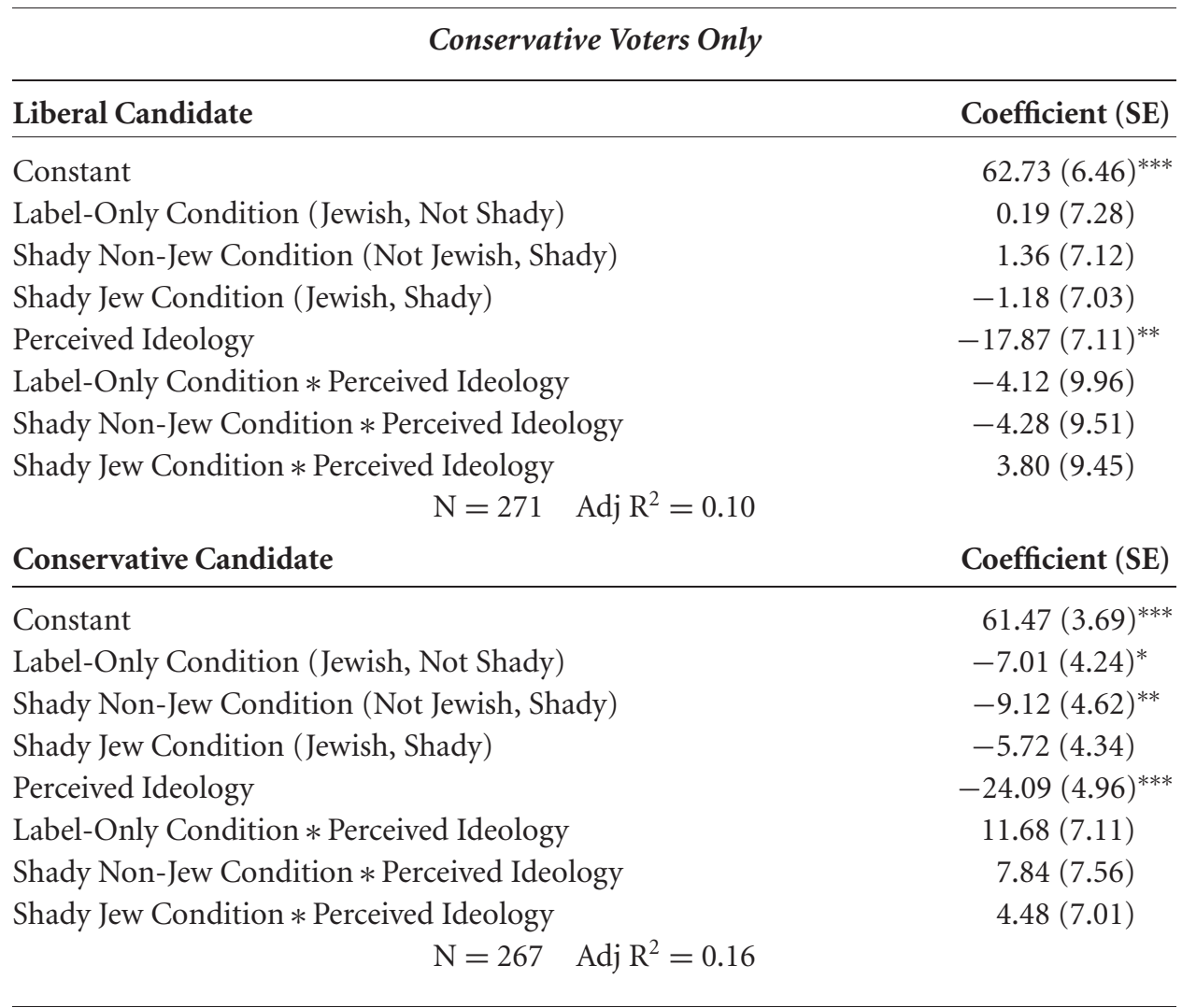




\section{TABle A1 The Impact of Perceived Candidate Ideology on Candidate Evaluation (Study 3) (continued)}

\begin{tabular}{|c|c|}
\hline \multicolumn{2}{|l|}{ Liberal Voters Only } \\
\hline Liberal Candidate & Coefficient (SE) \\
\hline Constant & $33.95(7.92)^{* * *}$ \\
\hline Label-Only Condition (Jewish, Not Shady) & $5.79(8.79)$ \\
\hline Shady Non-Jew Condition (Not Jewish, Shady) & $16.87(9.40)^{*}$ \\
\hline Shady Jew Condition (Jewish, Shady) & $5.55(8.59)$ \\
\hline Perceived Ideology & $19.25(9.03)^{* *}$ \\
\hline Label-Only Condition $*$ Perceived Ideology & $-2.39(12.01)$ \\
\hline Shady Non-Jew Condition $*$ Perceived Ideology & $-15.13(12.70)$ \\
\hline Shady Jew Condition $*$ Perceived Ideology & $-5.71(11.55)$ \\
\hline \multicolumn{2}{|l|}{$\mathrm{N}=164 \quad$ Adj $\mathrm{R}^{2}=0.05$} \\
\hline Conservative Candidate & Coefficient (SE) \\
\hline Constant & $30.55(4.86)^{* * *}$ \\
\hline Label-Only Condition (Jewish, Not Shady) & $3.68(5.43)$ \\
\hline Shady Non-Jew Condition (Not Jewish, Shady) & $-2.96(5.13)$ \\
\hline Shady Jew Condition (Jewish, Shady) & $1.66(5.22)$ \\
\hline Perceived Ideology & $16.39(7.55)^{* *}$ \\
\hline Label-Only Condition $*$ Perceived Ideology & $-13.40(12.47)$ \\
\hline Shady Non-Jew Condition $*$ Perceived Ideology & $5.89(10.36)$ \\
\hline Shady Jew Condition $*$ Perceived Ideology & $-14.40(10.92)$ \\
\hline $\mathrm{N}=167 \quad$ Adj $\mathrm{R}^{2}=0.05$ & \\
\hline
\end{tabular}

\section{Appendix B: Candidate Profiles \\ Study 1}

Now we are going to ask you some questions to see how voters such as yourself view candidates for public office. I'm going to read you a description of a politician. Please listen and remember what you can from the description.

Control, Liberal. Howard Wilson is a state representative who is considering running for an open seat in Congress. Wilson is a 48-year-old businessman who is married with two children. He has served in the state Senate for two terms. While in the Senate, Wilson has voted to raise spending on assistance to the poor, to increase government involvement in health care and for a tax relief plan for middle-class families. As a state senator he worked to expand his state's economic ties with several countries overseas. One potential problem for Wilson is a lawsuit filed against him by a business client who accuses Wilson of neglecting and ignoring his business practices, causing the client to lose a great deal of money. Wilson has denied the charge.

Label-Only, Liberal. ...48-year-old Jewish businessman......voted to raise spending on assistance to the poor, to increase government involvement in health care...... business client who accuses Wilson of neglecting and ignoring his business practices, causing the client to lose...

Label and Shady, Liberal. ...48-year-old Jewish businessman...... voted to raise spending on assistance to the poor, to increase government involvement in health care...... .business competitor who accuses Wilson of engaging in shady business practices to get ahead, causing the competitor to lose...

Control, Conservative. ...48-year-old businessman... ...voted to reduce spending on assistance to the poor, to decrease government involvement in health care... ...business client who accuses Wilson of neglecting and 
ignoring his business practices, causing the client to lose...

Label-Only, Conservative. ...48-year-old Jewish businessman...... voted to reduce spending on assistance to the poor, to decrease government involvement in health care...... business client who accuses Wilson of neglecting and ignoring his business practices, causing the client to lose...

Label and Shady, Conservative. ...48-year-old Jewish businessman...... voted to reduce spending on assistance to the poor, to decrease government involvement in health care......business competitor who accuses Wilson of engaging in shady business practices to get ahead, causing the competitor to lose...

\section{Study 2}

Label and Shady, Liberal. Howard Wilson is a state representative who is considering running for an open seat in Congress. Wilson is a 48-year-old Jewish businessman who is married with two children. He has served in the state Senate for two terms. While in the Senate, Wilson has voted to raise spending on assistance to the poor, to increase government involvement in health care and for a tax relief plan for middle-class families. As a state senator he worked to expand his state's economic ties with several countries overseas. One potential problem for Wilson is a lawsuit filed against him by a business competitor who accuses Wilson of engaging in shady business practices to get ahead, causing the competitor to lose a great deal of money. Wilson has denied the charge.

Label and Shady, Conservative. ...48-year-old Jewish businessman...... voted to reduce spending on assistance to the poor, to decrease government involvement in health care......business competitor who accuses Wilson of engaging in shady business practices to get ahead, causing the competitor to lose...

Control, Liberal. ...48-year-old Protestant businessman......voted to raise spending on assistance to the poor, to increase government involvement in health care... . . business competitor who accuses Wilson of engaging in shady business practices to get ahead, causing the competitor to lose a great deal of money...

Control, Conservative. ...48-year-old Protestant businessman...... voted to reduce spending on assistance to the poor, to decrease government involvement in health care......business competitor who accuses
Wilson of engaging in shady business practices to get ahead, causing the competitor to lose...

\section{Study 3}

Control, Liberal. Howard Wilson is a 48-year-old businessman and two-term member of the state legislature who is considering running for an open seat in Congress. While in the legislature, Wilson voted to greatly raise spending on assistance to the poor. He also voted to increase government involvement in health care. If elected to Congress, he plans to sponsor a tax relief plan for middleclass families, strengthen national security, and expand economic ties with several countries overseas. One potential problem for Wilson's campaign is a lawsuit filed against him by a business client who accuses Wilson of neglecting and ignoring his business practices, causing the client to lose a great deal of money. Wilson has denied the charge.

Label-Only, Liberal. ...48-year-old Jewish businessman...... voted to greatly raise spending on assistance to the poor. He also voted to increase government involvement in health care. .... . business client who accuses Wilson of neglecting and ignoring his business practices, causing the client to lose...

Shady, Liberal. . . .48-year-old businessman. . . ... voted to greatly raise spending on assistance to the poor. $\mathrm{He}$ also voted to increase government involvement in health care. . . . . .business competitor who accuses Wilson of engaging in shady business practices to get ahead, causing the competitor to lose...

Label and Shady, Liberal. ...48-year-old Jewish businessman.......voted to greatly raise spending on assistance to the poor. He also voted to increase government involvement in health care......business competitor who accuses Wilson of engaging in shady business practices to get ahead, causing the competitor to lose...

Control, Conservative. ...48-year-old businessman... ...voted to greatly reduce spending on assistance to the poor. He also voted to decrease government involvement in health care...... business client who accuses Wilson of neglecting and ignoring his business practices, causing the client to lose a great deal of money...

Label-Only, Conservative. ...48-year-old Jewish businessman.......voted to greatly reduce spending on assistance to the poor. He also voted to decrease government involvement in health care......business 
client who accuses Wilson of neglecting and ignoring his business practices, causing the client to lose. . .

Shady, Conservative. ...48-year-old businessman... ...voted to greatly reduce spending on assistance to the poor. He also voted to decrease government involvement in health care. . . . . business competitor who accuses Wilson of engaging in shady business practices to get ahead, causing the competitor to lose...
Label and Shady, Conservative. ...48-year-old Jewish businessman...... voted to greatly reduce spending on assistance to the poor. He also voted to decrease government involvement in health care. . . . . business competitor who accuses Wilson of engaging in shady business practices to get ahead, causing the competitor to lose...

[Note: Respondent is randomly assigned to one profile only.]

\section{Appendix C: Sample Characteristics, Variables, and Randomization Checks}

TABLE A2 Comparison of Stereotype Studies and 2000 NES

\begin{tabular}{|c|c|c|c|c|}
\hline Variable & $\begin{array}{l}\text { First } \\
\text { Study }\end{array}$ & $\begin{array}{c}\text { Second } \\
\text { Study }\end{array}$ & $\begin{array}{l}\text { Third } \\
\text { Study }\end{array}$ & $\begin{array}{l}2000 \\
\text { NES } \\
\end{array}$ \\
\hline \multicolumn{5}{|l|}{ Party identification } \\
\hline Republican & 31.5 & 30.3 & 33.0 & 25.0 \\
\hline Democrat & 28.7 & 33.3 & 35.3 & 34.3 \\
\hline Independent & 34.4 & 27.3 & 24.0 & 27.4 \\
\hline Other/don't know/no response & 5.4 & 9.0 & 7.6 & 13.3 \\
\hline \multicolumn{5}{|l|}{ Ideological self-placement } \\
\hline Conservative & 53.1 & 52.9 & 46.6 & 52.3 \\
\hline Liberal & 41.6 & 37.3 & 29.4 & 34.9 \\
\hline Moderate/other/don’t know ${ }^{1}$ & 5.3 & 9.8 & 24.0 & 12.8 \\
\hline $\begin{array}{l}\text { Preference on government spending } \\
\qquad(1=\text { reduce, } 7=\text { increase })\end{array}$ & 4.5 & & & 4.3 \\
\hline Age (mean) & 45.1 & 46.6 & 48.0 & 47.0 \\
\hline \multicolumn{5}{|l|}{ Education } \\
\hline Some high school or less & 7.0 & 6.1 & 6.2 & 10.0 \\
\hline High school diploma & 23.8 & 23.4 & 25.0 & 28.8 \\
\hline Some college or 2-year degree & 28.0 & 32.2 & 23.9 & 30.3 \\
\hline 4-year or more advanced degree & 41.2 & 38.3 & 44.9 & 30.9 \\
\hline Female & 56.0 & 63.8 & 58.0 & 56.3 \\
\hline \multicolumn{5}{|l|}{ Race } \\
\hline White & 79.6 & 76.8 & 76.5 & 86.0 \\
\hline Black/African American & 7.8 & 8.9 & 10.3 & 13.7 \\
\hline Asian/Pacific Islander & 1.5 & 1.7 & 1.7 & 0.0 \\
\hline American Indian/Native American & 1.1 & 1.9 & 1.9 & 0.0 \\
\hline Other/don’t know/no response & 10.0 & 10.7 & 9.6 & 0.3 \\
\hline \multicolumn{5}{|l|}{ Hispanic } \\
\hline Yes & 6.9 & 6.6 & 6.6 & 8.3 \\
\hline No & 91.8 & 91.9 & 93.2 & 85.8 \\
\hline Other/don't know/no response & 1.1 & 1.5 & 0.2 & 5.9 \\
\hline
\end{tabular}


TABLE A2 Comparison of Stereotype Studies and 2000 NES (continued)

\begin{tabular}{lcccc}
\hline Variable & $\begin{array}{c}\text { First } \\
\text { Study }\end{array}$ & $\begin{array}{c}\text { Second } \\
\text { Study }\end{array}$ & $\begin{array}{c}\text { Third } \\
\text { Study }\end{array}$ & $\begin{array}{c}\mathbf{2 0 0 0} \\
\text { NES }\end{array}$ \\
\hline $\begin{array}{l}\text { Household income } \\
\text { Up to } \$ 15,000\end{array}$ & & & & \\
\$15,000-\$24,999 & 8.1 & 8.1 & 9.4 & 13.3 \\
\$25,000-\$34,999 & 10.2 & 7.9 & 10.2 & 10.0 \\
$\$ 35,000-\$ 49,999$ & 11.3 & 12.1 & 14.5 & 11.5 \\
$\$ 50,000-\$ 74,999$ & 17.2 & 19.2 & 18.2 & 13.7 \\
$\$ 75,000-\$ 99,999$ & 11.6 & 15.4 & 21.6 & 7.8 \\
\$100,000 or more & 11.4 & 10.4 & 22.6 & 9.9 \\
Don't know & 9.8 & 2.6 & & 4.1 \\
Refusal & 2.0 & 11.7 & 0.8 & 8.5 \\
N & 9.4 & 531 & 1206 & 1807 \\
\hline
\end{tabular}

${ }^{1}$ The 2000 NES, unlike our study, provided an option of "haven't thought about it much." Most likely, those who selected this answer chose moderate or don't know in our study.

${ }^{2}$ Figure for $\$ 75,000$ or more.

For Study 1, N = 756, AAPOR's RR 3 response rate $=16 \%$. For Study 2, N = 531, AAPOR's RR 3 response rate $=21 \%$. For Study 3, N = 1206, AAPOR's RR3 rate $=29 \%$. Studies 1 and 2 were conducted by the Survey Research Center at Princeton University, and Study 3 was conducted by the Center for Survey Research of Indiana University. Study 1 was fielded from early February to April 2001, Study 2 from April to June 2002, and Study 3 during the summer and fall of 2003, each using random-digit dialing and a national voting-age sample.

Appendix D Variable Distributions
Study 1

\begin{tabular}{lccccccc}
\hline Howard Wilson's Perceived Ideology & & & & \\
\hline $\begin{array}{l}\text { Conservative- } \\
\text { Liberal Scale }\end{array}$ & 1 & 2 & 3 & 4 & 5 & 6 & 7 \\
$\begin{array}{l}\text { Percentage of } \\
\text { Respondents }\end{array}$ & 9.3 & 19.1 & 19.4 & 3.4 & 18.8 & 21.0 & 9.0 \\
\hline
\end{tabular}

Note: 7 is the most liberal response, and 1 is the most conservative response.

\begin{tabular}{lccccc}
\hline Feeling Thermometer for Howard Wilson & & \\
\hline Thermometer Ratings & $0-24$ & $25-49$ & 50 & $51-74$ & $75-100$ \\
Percentage of & 15.2 & 23.9 & 40.7 & 13.6 & 6.6 \\
$\quad$ Respondents & & & & & \\
\hline
\end{tabular}

Randomization Check. For all studies the number of subjects is randomly distributed across conditions, with cell size ranging from 122 to 130 in Study 1, from 122 to 143 in Study 2, and from 138 to 165 in Study 3. Every relevant variable is randomly distributed across conditions with the exception of education in Study 1. When we included education in our basic models the results were substantially the same as those we report in the text.

\section{References}

Allport, Gordon W. 1954. The Nature of Prejudice. Cambridge: Addison-Wesley Publishing Company.

Arkes, Hal, and Philip Tetlock. 2004. "Attributions of Implicit Prejudice, or "Would Jesse Jackson "Fail" the Implicit Association Test?" Psychological Inquiry 15(4):257-78.

Anderson, John R. 1985. Cognitive Psychology and Its Implications, $2^{\text {nd }}$ ed. New York: W.H. Freeman.

Banaji, M.R., and A.G. Greenwald. 1994. "Implicit Stereotyping and Prejudice." In The Psychology of Prejudice: The Ontario Symposium, ed. M.P. Zanna and J.M. Olson. Hillsdale: Lawrence Erlbaum Associates, pp. 55-76.

Bargh, John A. 1996. "Automaticity in Social Psychology." In Social Psychology: Handbook of Basic Principles, ed. E. Tory Higgins and Arie W. Kruglanski. New York: Guilford Press, pp. 169-83.

Bodenhausen, G.V., and C.N. Macrae. 1998. "Stereotype Activation and Inhibition." In Stereotype Activation and Inhibition, ed. R.S. Wyer, Jr. Mahwah, NJ: Erlbaum, pp. 1-52.

Chanes, Jerome A. 1995. "Antisemitism and Jewish Security in America Today: Interpreting the Data." In Antisemitism in America Today: Outspoken Experts Explode the Myths, ed. Jerome A. Chanes. New York: Birch Lane Press, pp. 3-30.

Cohen, S.M., and C.S. Liebman. 1997. "American Jewish Liberalism: Unraveling the Strands.” Public Opinion Quarterly 61(Autumn):405-30.

Conover, Pamela Johnston, and Stanley Feldman. 1989. “Candidate Perception In An Ambiguous World: Campaigns, Cues 
And Inference Processes." American Journal of Political Science 33(4):912-40.

Converse, Philip E. 1964. "The Nature of Belief Systems in Mass Publics." In Ideology and Discontent, ed. David E. Apter. New York: Free Press, pp. 206-61.

Correll, J., B. Park, C.M. Judd, and B. Wittenbrink. 2002. "The Police Officer's Dilemma.” Journal of Personality and Social Psychology 83(6):1314-29.

Devine, Patricia G. 1989. "Stereotypes and Prejudice: Their Automatic and Controlled Components." Journal of Personality and Social Psychology 56(1):5-18.

Devine, Patricia G., and Kristin A. Vasquez. 1998. "The Rocky Road to Positive Intergroup Relations." In Confronting Racism: The Problem and the Response, ed. Jennifer Lynn Eberhardt and Susan T. Fiske. Thousand Oaks, CA: Sage Publications, Inc., pp. 234-62.

Dinnerstein, Leonard. 1994. Antisemitism in America. New York: Oxford.

Dovidio, J.F., N. Evans, and R.B. Tyler. 1986. "Racial Stereotypes: The Contents of their Cognitive Representations." Journal of Experimental Social Psychology 22(1):22-37.

Fazio, Russell H., Joni R. Jackson, Bridget C. Dunton, and Carol J. Williams. 1995. "Variability in Automatic Activation as an Unobtrusive Measure of Racial Attitudes: A Bona Fide Pipeline?" Journal of Personality and Social Psychology 69(6):1013-27.

Fiske, Susan T. 1998. "Stereotyping, Prejudice, and Discrimination." In The Handbook of Social Psychology, $4^{\text {th }}$ ed., ed. Daniel T. Gilbert, Susan T. Fiske, and Gardner Lindzey. New York: McGraw Hill, pp. 357-411.

Fiske, Susan T., and Steven L. Neuberg. 1990. "A Continuum Model of Impression Formation, from Attention and Interpretation." In Advances in Experimental Social Psychology, ed. Mark P. Zanna. New York: Academic Press, pp. 1-74.

Fiske, Susan T., and Shelley E. Taylor. 1984. Social Cognition. Reading, MA: Addison-Wesley.

Fiske, Susan T., Steven L. Neuberg, Ann E. Beattie, and Sandra J. Milberg. 1987. "Category-Based and Attribute-Based Reactions to Others." Journal of Experimental Social Psychology 23(5):399-427.

Foltin, Richard T. 1997. "National Affairs.” In American Jewish Year Book 1997, ed. David Singer and Ruth R. Seldin. New York: The American Jewish Committee, pp. 141-75.

Foltin, Richard T. 2000. "National Affairs.” In American Jewish Year Book 2000, ed. David Singer and Lawrence Grossman. New York: The American Jewish Committee, pp. 149-88.

Gilens, Martin. 1999. Why Americans Hate Welfare. Chicago: University of Chicago Press.

Gilliam, Frank D., and Shanto Iyengar. 2000. "Prime Suspects: The Influence of Local Television News on the Viewing Public." American Journal of Political Science 44(3):560-73.

Glaser, James M. 1997. "Toward an Explanation of the Racial Liberalism of American Jews." Political Research Quarterly 50(2):437-58.

Golebiowska, Ewa. 2001. "Group Stereotypes and Political Evaluation." American Politics Research 29(6):535-65.

Huddy, Leonie. 1998. "The Social Nature of Political Identity: Feminist Image and Feminist Identity." Presented at the Annual Meeting of the American Political Science Association, Boston.
Huddy, Leonie, and Nayda Terkildsen. 1993. "Gender Stereotypes and the Perception of Male and Female Candidates." American Journal of Political Science 37(1):11947.

Judd, Charles M., and James W. Downing. 1995. "Stereotypic Accuracy in Judgments of the Political Positions of Groups and Individuals." In Political Judgment: Structure and Process, ed. Milton Lodge and Kathleen M. McGraw. Ann Arbor: The University of Michigan Press, pp. 65-90.

Kahn, Kim F. 1994. “Does Gender Make a Difference? An Experimental Examination of Sex Stereotypes and Press Patterns in Statewide Campaigns.” American Journal of Political Science 38(1):162-95.

Kinder, Donald R., and Lynn M. Sanders. 1996. Divided by Color: Racial Politics and Democratic Ideals. Chicago: Chicago University Press.

Lau, Richard. 1986. "Political Schemata, Candidate Evaluations, and Voting Behavior." In Political Cognition: The 19th Annual Carnegie Symposium on Cognition, ed. Richard R. Lau and David O. Sears. Hillsdale: Lawrence Erlbaum, pp. 95126.

Lau, Richard, and David P. Redlawsk. 2001. "Advantages and Disadvantages of Cognitive Heuristics in Political Decision Making." American Journal of Political Science 45(4):95171.

Limbaugh, Rush. 2001. Rush Online.com: Goreisms. http://www. rushonle.com/visitors/goreism.htm (October 27, 2003).

Lippmann, Walter. 1922. Public Opinion. New York: Harcourt, Brace and Co.

Lodge, Milton, and Patrick Stroh. 1993. "Inside the Mental Voting Booth: An Impression-Driven Process Model of Candidate Evaluation." In Explorations in Political Psychology, ed. Shanto Iyengar and William J. McGuire. Durham: Duke University Press, pp. 225-63.

Lodge, Milton, Kathleen M. McGraw, and Patrick Stroh. 1989. "An Impression Driven Model of Candidate Evaluation." American Political Science Review 83(2):399-419.

Macrae, C. Neil, Alan B. Milne, and Galen V. Bodenhausen. 1994. "Stereotypes as Energy Saving Devices: A Peek Inside the Cognitive Toolbox." Journal of Personality and Social Psychology 66(1):37-47.

Macrae, C. Neil, Charles Stangor, and Alan B. Milne. 1994. "Activating Social Stereotypes: A functional analysis." Journal of Experimental Social Psychology 30(4):370-89.

McDermott, Monika L. 1997. "Voting Cues in Low-Information Elections: Candidate Gender as a Social Information Variable in Contemporary United States Elections." American Journal of Political Science 41(1):270-83.

McGraw, Kathleen M., and Marco Steenbergen. 1995. "Pictures in the Head: Memory Representations of Political Candidates." In Political Judgment: Structure and Process, ed. Milton Lodge and Kathleen M. McGraw. Ann Arbor: The University of Michigan Press, pp. 15-42.

McIntire, Mike. 2000. "Records Refute GOP 'Hypocrite' Claim.” Hartford Courant, pg. A10, September 14.

Mendelberg, Tali. 2001. The Race Card: Campaign Strategy, Implicit Messages, and the Norm of Equality. Princeton: Princeton University Press.

Merida, Kevin. 1994. "Failure to Repudiate Sen. Hollings Puzzles Black Lawmakers.” Washington Post, pg. A7, February 5. 
Meryhew, Richard. 2001. "In Iowa, Strangers Become Neighbors.” Minneapolis Star Tribune, pg. A1, February 19.

Monteith, Margo J. 1993. "Self-Regulation of Prejudiced Responses: Implications for Progress in Prejudice-Reduction Efforts." Journal of Personality and Social Psychology 65(3):469-85.

Murphy, Dean E. 2005. "Case Stirs Fight on Jews, Juries and Execution." New York Times, p. A1, March 16.

Nelson, Thomas E., and Donald R. Kinder. 1996. "Issue Frames and Group-Centrism in American Public Opinion." Journal of Politics 58(4):1055-78.

Nelson, Thomas E., Michele Acker, and Melvin Manis. 1996. "Irrepressible Stereotypes." Journal of Experimental Social Psychology 32(1):13-38.

Operario, Don, and Susan T. Fiske. 1998. "Racism Equals Power Plus Prejudice: A Social Psychological Equation for Racial Oppression." In Confronting Racism: The Problem and the Response, ed. Jennifer L. Eberhardt and Susan T. Fiske. Thousand Oaks: Sage, pp. 33-53.

Page, Benjamin I. 1978. Choices and Echoes in Presidential Elections. Chicago: University of Chicago Press.

Peffley, Mark, and Jon Hurwitz. 1998. "Whites' Stereotypes of Blacks: Sources and Political Consequences." In Perception and Prejudice: Race and Politics in the United States, ed. Jon Hurwitz and Mark Peffley. New Haven: Yale University Press, pp. 58-99.

Rahn, Wendy M. 1993. “The Role of Partisan Stereotypes in Information Processing about Political Candidates." American Journal of Political Science 37(2):472-96.

Sears, David O., Jim Sidanius, and Lawrence Bobo, eds. 2000. Racialized Politics: The Debate About Racism in America. Chicago: University of Chicago Press.

Sigelman, Lee. 1991. "'If You Prick Us, Do We Not Bleed? If You Tickle Us, Do We Not Laugh?' Jews and Pocketbook Voting.” Journal of Politics 53(4):977-92.

Sigelman, Carol K., Lee Sigelman, Barbara J. Walkosz, and Michael Nitz. 1995. "Black Candidates, White Voters: Un- derstanding Racial Bias in Political Perceptions." American Journal of Political Science 39(1):243-65.

Smith, Tom W. 1993. "Actual Trends or Measurement Artifacts? A Review of Three Studies of Anti-Semitism.” Public Opinion Quarterly 57(Autumn):380-93.

Sniderman, Paul, and Thomas Piazza. 1993. The Scar of Race. Cambridge: Harvard University.

Taber, Charles S., Milton Lodge, and Jill Glathar. 2001. "The Motivated Construction of Political Judgments." In Citizens and Politics: Perspectives from Political Psychology, ed. James M. Kuklinski. New York: Cambridge University Press, pp. 198-226.

Terkildsen, Nayda. 1993. "When White Voters Evaluate Black Candidates: The Processing Implications of Candidate Skin Color, Prejudice, and Self-Monitoring." American Journal of Political Science 37(4):1032-53.

Valentino, Nicholas, Vincent Hutchings, and Ismail White. 2002. "Cues that Matter: How Political Ads Prime Racial Attitudes During Campaigns." American Political Science Review 96(1):75-90.

Vavreck, Lynn. 2001. “The Reasoning Voter Meets the Strategic Candidate: Signals and Specificity in Campaign Advertising, 1998." American Politics Research 29(5):507-29.

Wayne, Leslie, and Don Van Natta, Jr. 2000. "The 2000 Campaign: The Democratic Running Mate; As a Senator, Lieberman is Proudly Pro-Business." New York Times, pg. A1, August 27.

Wertheimer, Jack. 1995. "Antisemitism in the United States: A Historical Perspective." In Antisemitism in America Today: Outspoken Experts Explode the Myths, ed. Jerome A. Chanes. New York: Birch Lane Press, pp. 33-58.

Wittenbrink, Bernd, Charles M. Judd, and Bernadette Park. 1997. "Evidence for Racial Prejudice at the Implicit Level and Its Relationship with Questionnaire Measures.” Journal of Personality and Social Psychology 72(2):262-74.

Wyatt, Edward. 2003. "Lieberman, the Centrist in the Middle of the Pack.” New York Times, pg. A1, October 13. 